\section{Kidney \\ Blood Pressure Research}

Kidney Blood Press Res 2012;36:258-267

\begin{tabular}{l|l}
\hline DOI: $10.1159 / 000343415$ & (c) 2012 S. Karger AG, Basel \\
\hline
\end{tabular}

www.karger.com/kbr

$1420-4096 / 12 / 0361-0258 \$ 38.00 / 0$

\title{
Effects of Endothelin Receptor Antagonists on Renal Hemodynamics in Angiotensin II- Infused Rats on High $\mathrm{NaCl}$ Intake
}

\author{
Aso Saeed ${ }^{a}$ Gerald F. DiBona ${ }^{b} \quad$ Gregor Guron ${ }^{a}$ \\ aDepartment of Molecular and Clinical Medicine/Nephrology, Institute of Medicine, The Sahlgrenska \\ Academy at the University of Gothenburg, Sweden, bDepartments of Internal Medicine and Molecular \\ Physiology and Biophysics, Department of Veterans Affairs Medical Center and University of Iowa \\ Carver College of Medicine, Iowa City, Iowa, USA
}

\section{Key Words}

Angiotensin II • Endothelin • Renal blood flow $\bullet$ Renal autoregulation $\bullet$ Renal medullary blood flow

\begin{abstract}
Aim: The aim was to investigate effects of selective endothelin (ET) receptor antagonists on renal hemodynamics and dynamic renal blood flow autoregulation (RBFA) in angiotensin II (Ang II)-infused rats on a high $\mathrm{NaCl}$ intake. Methods: Sprague-Dawley rats received Ang II (250 $\mathrm{ng} / \mathrm{kg} / \mathrm{min}$, s.c.) and an $8 \% \mathrm{NaCl}$ diet for 14 days after which renal clearance experiments were performed. After baseline measurements animals were administered either: (a) saline vehicle; (b) $\mathrm{ET}_{\mathrm{A}}$ receptor antagonist $\mathrm{BQ}-123(30 \mathrm{nmol} / \mathrm{kg} / \mathrm{min}) ;$ (c) $\mathrm{ET}_{\mathrm{B}}$ receptor antagonist $\mathrm{BQ}-788$ (30 nmol $/ \mathrm{kg} / \mathrm{min}$ ); or (d) BQ-123 + BQ-788, for six consecutive 20 -minute clearance periods. Results: BQ-123 reduced arterial pressure (AP) and selectively increased outer medullary perfusion versus vehicle $(p<0.05)$. These effects were attenuated or abolished by combined BQ-123 and BQ-788. BQ-788 reduced renal blood flow and increased renovascular resistance $(p<0.05)$. Ang II-infused rats on high $\mathrm{NaCl}$ intake showed abnormalities in dynamic RBFA characterized by an impaired myogenic response that were not significantly affected by ET receptor antagonists. Conclusion: In hypertensive Ang II-infused rats on a high- $\mathrm{NaCl}$ intake selective $\mathrm{ET}_{\mathrm{A}}$ antagonism with $\mathrm{BQ}-123$ reduced $\mathrm{AP}$ and specifically increased $\mathrm{OM}$ perfusion and these effects were dependent on intact $\mathrm{ET}_{B}$ receptor stimulation. Furthermore, $\mathrm{ET}$ receptor antagonists did not attenuate abnormalities in dynamic RBFA.
\end{abstract}




\section{Kidney Blood Pressure Research}

Kidney Blood Press Res 2012;36:258-267

\begin{tabular}{l|l}
\hline DOI: $10.1159 / 000343415$ & (c) 2012 S. Karger AG, Basel \\
\hline
\end{tabular}

Published online: November 26, 2012

www.karger.com/kbr

Saeed/DiBona/Guron: Endothelin and Renal Hemodynamics

\section{Introduction}

Endothelin (ET)-1 is a potent vasoactive peptide that has important roles in the regulation of kidney function and arterial pressure (AP) [1]. Endothelin-1 exerts its biological actions through two major receptor subtypes in mammals; $\mathrm{ET}_{\mathrm{A}}$ and $\mathrm{ET}_{\mathrm{B}}$. The vascular effects of ET-1 are influenced by the distribution and relative abundance of ET and $\mathrm{ET}_{\mathrm{B}}$ receptors. Activation of $\mathrm{ET}_{\mathrm{A}}$ and $\mathrm{ET}_{\mathrm{B}}$ receptors on vascular smooth muscle cells (VSMCs) mediates vasoconstriction whereas activation of endothelial $\mathrm{ET}_{\mathrm{B}}$ receptors produce vasodilatation which is mainly caused by activation of nitric oxide synthase (NOS) and NO [1-3]. In the kidney, ET-1 also regulates tubular sodium and water reabsorption mainly in the thick ascending limb and collecting duct (CD) [4] although there may also be effects in proximal tubules [5]. Interestingly, the highest tissue levels of ET-1 in the body are found in the renal medulla [6] where ET-1 is mainly synthesized by CD cells and acts in an autocrine and paracrine manner [1]. Endothelin-1 production by the CD is increased in natriuretic situations and ET- 1 inhibits CD sodium and water reabsorption predominantly through ET $_{B}$ receptors on CD cells [1, 4]. However, ET-1 also modulates medullary blood flow $[7,8]$ and may inhibit tubular sodium reabsorption by causing medullary vasodilatation [9]. Infusion of Big ET-1 produces selective vasodilatation in the renal medulla in rats on a high $\mathrm{NaCl}$ intake via $\mathrm{ET}_{\mathrm{B}}$ receptors [9]. In addition, $\mathrm{ET}_{\mathrm{B}}$ receptor antagonism has been shown to reduce medullary blood flow and to blunt the pressure natriuresis relationship in rats on a high $\mathrm{NaCl}$ intake [9]. Furthermore, rats deficient in $\mathrm{ET}_{\mathrm{B}}$ receptors [10] and mice with collecting duct-specific deletion of ET-1 [11], $\mathrm{ET}_{B}$ receptors [12], or $\mathrm{ET}_{\mathrm{A}}$ and $\mathrm{ET}_{\mathrm{B}}$ receptors [13], develop hypertension that is exaggerated by a high $\mathrm{NaCl}$ intake. Taken together, ET- 1 in the renal medulla is involved in long-term AP regulation, particularly during high $\mathrm{NaCl}$ intake and exerts antihypertensive effects primarily via $\mathrm{ET}_{\mathrm{B}}$ receptors by promoting urinary sodium and water excretion. Besides the role of renal $\mathrm{ET}_{\mathrm{B}}$ receptor in regulation of $\mathrm{AP}$ by modulating tubular sodium and water reabsorption, ET-1 may also act as an amplifier of the pressor effects of Ang II [14]. Several factors can stimulate intrarenal ET-1 synthesis, including Ang II $[15,16]$. Thus, ET-1 may contribute to hypertension in Ang II-dependent forms of hypertension. Most pressor effects of ET-1 are mediated by activation of the $\mathrm{ET}_{\mathrm{A}}$ receptor $[1,17]$. The antihypertensive effect of $\mathrm{ET}_{\mathrm{A}}$ receptor antagonists has been shown to be more prominent in Ang II-infused rats on a high $\mathrm{NaCl}$ diet compared to those on a normal $\mathrm{NaCl}$ diet [18]. In line with these results $\mathrm{ET}_{\mathrm{A}}$ receptor antagonists lower $\mathrm{AP}$ in other salt-sensitive models of hypertension $[19,20]$.

We have previously shown that rats with hypertension caused by chronic Ang IIinfusion and a high $\mathrm{NaCl}$ intake develop a marked increase in renovascular resistance and impairments in dynamic RBF autoregulation (RBFA) characterized by an abnormal myogenic response [21]. We hypothesized that ET-1 might contribute to these abnormalities in renal hemodynamics in this model. Hence, the aim of the present study was to investigate the effects of selective $\mathrm{ET}_{\mathrm{A}}$ and/or $\mathrm{ET}_{\mathrm{B}}$ receptor antagonists on intrarenal hemodynamics and dynamic RBFA in Ang II-infused rats on a high $\mathrm{NaCl}$ diet.

\section{Materials and Methods}

\section{General procedures}

Male Sprague-Dawley rats (Harlan, Horst, The Netherlands) weighing approximately $300 \mathrm{~g}$ were used. Rats had free access to chow and tap water and were kept in rooms with a controlled temperature of $24-26^{\circ}$ C and a 12:12 h dark-light cycle. Chemicals were from Sigma (St. Louis, MO, USA) if not stated otherwise. Endothelin receptor antagonists BQ-123 and BQ-788 were purchased from Peptides Int. (Louisville, KY, USA). These agents have been widely used previously and at acceptable side effects [22-26].

\section{Protocol}

Rats received Ang II (250 ng/kg/min, s.c.) via osmotic minipumps (Alzet model 2002) and a high $\mathrm{NaCl}$ (HNa, $8 \% \mathrm{NaCl}$ ) diet (Lantmännen, Sweden) for 14 days after which renal clearance experiments were 


\section{Kidney Blood Pressure Research}

performed. After two 20-minute baseline clearance periods, rats were intravenously (i.v.) administered either: (a) isotonic saline vehicle (AngII HNa-vehicle, $\mathrm{n}=8$ ); (b) the $\mathrm{ET}_{\mathrm{A}}$ receptor antagonist BQ-123 (30 $\mathrm{nmol} / \mathrm{kg} / \mathrm{min}$, AngII HNa-BQ123, n=9); (c) the $\mathrm{ET}_{\mathrm{B}}$ receptor antagonist BQ-788 (30 nmol $/ \mathrm{kg} / \mathrm{min}$, AngII HNa-BQ788, n=10); or (d) BQ-123 + BQ-788 (both in doses of $30 \mathrm{nmol} / \mathrm{kg} / \mathrm{min}$, AngII HNa-BQ123+BQ788, $\mathrm{n}=9$ ). Based on previous studies these doses were expected to result in steady state plasma concentrations that completely block responses to both endogenous and exogenous $(0.3 \mathrm{nmol} / \mathrm{kg}$, i.v. bolus) ET- 1 via ET and $\mathrm{ET}_{\mathrm{B}}$ receptors within approximately 60 minutes [22-24]. Drugs and vehicle saline were infused in equivalent volumes of $4 \mathrm{ml} / \mathrm{kg} / \mathrm{h}$ throughout six consecutive 20 -minute clearance periods.

\section{Surgical preparation and measurements}

Rats were anaesthetized with thiobutabarbital (Inactin, $120 \mathrm{mg} / \mathrm{kg}$ i.p.), placed on a heating table, and surgically prepared for renal clearance experiments as described [27]. An AP catheter inserted via the femoral artery was connected to a pressure transducer (Smiths Medical, Kirchseeon, Germany) for monitoring of AP, pulsatile and mean (MAP) and heart rate (HR) using a data acquisition program (Biopac MP 150, Biopac Systems, Santa Barbara, CA, USA). Infusions of saline and drugs were administered through a femoral vein catheter. The left kidney was exposed by a flank incision and immobilized in a plastic cup. The left ureter was catheterized for urine collection. Rectal and kidney temperatures were kept at $37^{\circ} \mathrm{C}$. A perivascular ultrasonic transit-time flow probe (0.7 VB, T206, Transonic Systems Inc., Ithaca, NY, USA) was placed around the left renal artery for measurement of RBF. Renal cortical (CLDF) and outer medullary (OMLDF) laser-Doppler fluxes were measured by laser-Doppler flowmetry (PF5000; Perimed, Stockholm, Sweden). Outer medullary perfusion was measured by a needle probe (411; Perimed) at a depth of $3.5 \mathrm{~mm}$ into the kidney, as described previously [27]. The laser-Doppler signal has been demonstrated previously to provide an adequate estimate of regional tissue blood flow in the kidney [28].

Glomerular filtration rate (GFR) was determined by measuring renal ${ }^{51} \mathrm{Cr}$-EDTA clearance $\left({ }^{51} \mathrm{Cr}-\right.$ ethylenediamine tetraacetic acid, Amersham Laboratories, Buckinghamshire, UK), as described [29]. Blood was sampled at the start and completion of each 20-minute clearance period and mean values of plasma radioactivity were used to calculate GFR. Arterial blood samples $(0.3 \mathrm{ml})$ were replaced by equivalent volumes of $4 \%$ bovine serum albumin in isotonic saline. Rats were infused with a total volume of $10 \mathrm{ml} /$ $\mathrm{kg} / \mathrm{h}$ of isotonic saline throughout. Rats were killed by an overdose of pentobarbital sodium. Renal vascular resistance (RVR) was calculated as MAP ( $\mathrm{mmHg}$ )/RBF (ml/min/g kidney weight [KW]). Filtration fraction (FF) was calculated as GFR/RBF as haematocrit was not measured and hence renal plasma flow could not be calculated.

\section{Transfer function analysis}

To evaluate effects of ET receptor antagonists on dynamic RBFA, data from baseline clearance periods and the last two periods (i.e. $\mathrm{C} 7+\mathrm{C} 8,80-120$ minutes after start of drug administration) were subjected to power spectral and transfer function analyses using methods previously described in detail [21]. Data over the range of frequencies for the myogenic response (0.08-0.18) and the tubuloglomerular feedback (TGF) mechanism (0.03-0.06) were analysed [21,30,31]. The slope of gain decrease in the frequency range of the myogenic response was determined by least squares fitting of the linear regression of gain decrease and the phase peak was estimated as the average phase value within the same frequency interval. In addition, to assess the contribution of the myogenic response to RBFA, mean gain values in the frequency range of 0.06-0.09 Hz were used to minimize corruption by TGF $(<0.06 \mathrm{~Hz})$ and by myogenic transients $(>0.09 \mathrm{~Hz})$ $[21,32]$.

\section{Statistical analysis}

All values are means \pm SEM. Analyses were performed using one-way analysis of variance (ANOVA). Normality was tested with the Shapiro-Wilk test and equality of variances was assessed by Levene's test. If data were not normally distributed or had unequal variances, Kruskal-Wallis one-way ANOVA on ranks was used. Unpaired t-test or Mann-Whitney U test was used when appropriate. Bonferroni corrections were made for multiple comparisons. To reduce the number of comparisons no statistical analyses were made between groups AngII HNa-BQ123 and AngII HNa-BQ788. To assess drug effects, the area under/ over the curve (AUC, AOC) for the intervention period was calculated by the trapezoidal formula using the statistical program Prism version 5 (GraphPad Software Inc., San Diego, CA). A P value $<0.05$ was considered statistically significant. The statistical software SPSS 17.0 (SPSS Inc., Chicago, Illinois, USA) was used. 


\section{Kidney Blood Pressure Research}

Table 1. Renal hemodynamics and function at baseline, prior to drug administration

\begin{tabular}{lccccc}
\hline & $\begin{array}{c}\text { AngII HNa- } \\
\text { vehicle } \\
(\mathrm{n}=8)\end{array}$ & $\begin{array}{c}\text { AngIl HNa- } \\
\text { BQ123 } \\
(\mathrm{n}=9)\end{array}$ & $\begin{array}{c}\text { AngII HNa- } \\
\text { BQ788 } \\
(\mathrm{n}=10)\end{array}$ & $\begin{array}{c}\text { AngII HNa- } \\
\text { BQ123+BQ788 } \\
(\mathrm{n}=9)\end{array}$ & ANOVA \\
\hline Body weight $(\mathrm{g})$ & $281 \pm 16$ & $261 \pm 11$ & $263 \pm 6$ & $262 \pm 8$ & $\mathrm{~ns}$ \\
$\mathrm{MAP}(\mathrm{mmHg})$ & $156 \pm 4$ & $146 \pm 4$ & $144 \pm 5$ & $146 \pm 2$ & $\mathrm{~ns}$ \\
$\mathrm{HR}(\mathrm{bpm})$ & $392 \pm 10$ & $373 \pm 12$ & $374 \pm 9$ & $393 \pm 6$ & $\mathrm{~ns}$ \\
$\mathrm{GFR}(\mathrm{ml} / \mathrm{min} / \mathrm{g} \mathrm{KW})$ & $1.40 \pm 0.04$ & $1.22 \pm 0.10$ & $1.10 \pm 0.08$ & $1.19 \pm 0.05$ & $\mathrm{~ns}$ \\
$\mathrm{RBF}(\mathrm{ml} / \mathrm{min} / \mathrm{g} \mathrm{KW})$ & $6.0 \pm 0.3$ & $6.1 \pm 0.3$ & $5.8 \pm 0.3$ & $6.5 \pm 0.3$ & $\mathrm{~ns}$ \\
$\mathrm{RVR}(\mathrm{mmHg} /[\mathrm{ml} / \mathrm{min} / \mathrm{g} \mathrm{KW]})$ & $26.4 \pm 1.6$ & $24.4 \pm 1.4$ & $25.6 \pm 1.5$ & $22.9 \pm 1.1$ & $\mathrm{~ns}$ \\
$\mathrm{FF}(\mathrm{GFR} / \mathrm{RBF}, \%)$ & $23.5 \pm 0.7$ & $20.4 \pm 1.7$ & $19.3 \pm 1.1^{*}$ & $18.6 \pm 0.9 *$ & $\mathrm{p}<0.05$ \\
$\mathrm{UV}(\mu \mathrm{min} / \mathrm{g} \mathrm{KW})$ & $32.8 \pm 5.8$ & $45.5 \pm 11.4$ & $39.1 \pm 12.8$ & $13.5 \pm 2.3^{*} \dagger \neq$ & $\mathrm{p}<0.05$ \\
$\mathrm{U}_{\mathrm{NaV}}(\mu \mathrm{mol} / \mathrm{min} / \mathrm{g} \mathrm{KW})$ & $6.27 \pm 0.95$ & $4.67 \pm 0.83$ & $6.31 \pm 1.82$ & $2.17 \pm 0.44 \dagger \neq$ & $\mathrm{p}<0.05$ \\
$\mathrm{FE}(\%)$ & $3.07 \pm 0.47$ & $3.89 \pm 0.92$ & $4.84 \pm 1.31$ & $1.77 \pm 0.34 \dagger \neq$ & $\mathrm{p}<0.05$ \\
\hline
\end{tabular}

Data are means \pm SEM of two baseline 20 -minute clearance periods prior to drug administration in thiobutabarbital anesthetized rats (see Methods). MAP, mean arterial pressure; BW, body weight; HR, heart rate; GFR, glomerular filtration rate; KW, kidney weight; RBF, renal blood flow; RVR, renal vascular resistance; $F F$, filtration fraction; $U V$, urine flow rate; $F E_{N a}$, fractional urinary sodium excretion, $U_{N a V}$, urinary sodium excretion. ${ }^{*} P<0.05$ vs. AngII HNa-Vehicle, $\dagger P<0.05$ vs. AngII HNa-BQ123 and $\ddagger P<0.05$ vs. AngII HNa-BQ788. There were no statistically significant differences between groups in kidney weight.

\section{Results}

\section{Renal hemodynamics and function at baseline}

At baseline, prior to drug administration, there were no significant differences between groups in MAP, RBF, RVR or GFR (Table 1). There were statistically significant differences between groups in FF, urine flow rate and urinary sodium excretion $(\mathrm{p}<0.05$, Table1).

Renal hemodynamics and function - effects of $E T_{A}$ and $E T_{B}$ receptor antagonists

Effects of $B Q-123$. BQ-123 reduced MAP versus (vs.) vehicle $(\mathrm{p}<0.05$, Figure $1 \mathrm{~A})$. In addition, group AngII HNa-BQ123 showed a progressive increase in OMLDF vs. AngII HNavehicle $(\mathrm{p}<0.05)$ whereas total RBF and CLDF were not significantly affected (Figure 2). During the last clearance period OMLDF had increased by $29 \pm 8 \%$ vs. baseline in AngII HNa$\mathrm{BQ123}$. Combined treatment with BQ-123 and BQ-788 abolished the increase in OMLDF produced by BQ-123 alone ( $\mathrm{p}<0.05$, AngII HNa-BQ123+BQ788 vs. AngII HNa-BQ123, Figure 2C). BQ-123 had no statistically significant effects on GFR, urine flow rate or absolute or fractional urinary sodium excretion (Figures 3 and 4).

Effects of BQ-788. BQ-788 caused a continuous decrease in $\mathrm{RBF}$ ( $\mathrm{p}<0.05$ vs. vehicle) and during the final clearance period RBF had decreased by $29 \pm 3 \%$ vs. baseline (Figure 2A). BQ788 had no statistically significant effects on MAP or GFR and hence RVR and FF increased significantly vs. vehicle ( $p<0.05$, Figures 1 and 3 ). BQ-788 had no statistically significant effects on cortical or outer medullary perfusion (Figure 2). Combined treatment with BQ-123 and $\mathrm{BQ}-788$ abolished the effects of $\mathrm{BQ}-788$ alone, and there were no statistically significant differences between groups AngII HNa-BQ123+BQ788 and AngII HNa-vehicle in RBF, RVR of $\mathrm{FF}$ (Figures 1B, 2A and $3 \mathrm{~B}$ ). In addition, MAP and RVR were significantly reduced (Figures 1), and HR increased (data not shown), in AngII HNa-BQ123+BQ788 vs. AngII HNa-BQ788 $(\mathrm{p}<0.05)$. BQ-788 had no statistically significant effects on urine flow rate or absolute or fractional urinary sodium excretion (Figure 4).

\section{Transfer function analysis of renal blood flow autoregulation}

At baseline, prior to drug administration, the normal distinct transition in gain from positive to negative values in the frequency range of the myogenic response did not occur, or was attenuated, in all groups and the corresponding local maximum in phase was missing, or blunted, indicating an impaired myogenic response (Table 2 and Figures S1-4). Supplemental figures can be seen at the authors department web-page by using the following link-address: http://www.medicine.gu.se/mkm/njurmedicin/artikelbilder/. In addition, gain values 


\section{Kidney \\ Blood Pressure Research}

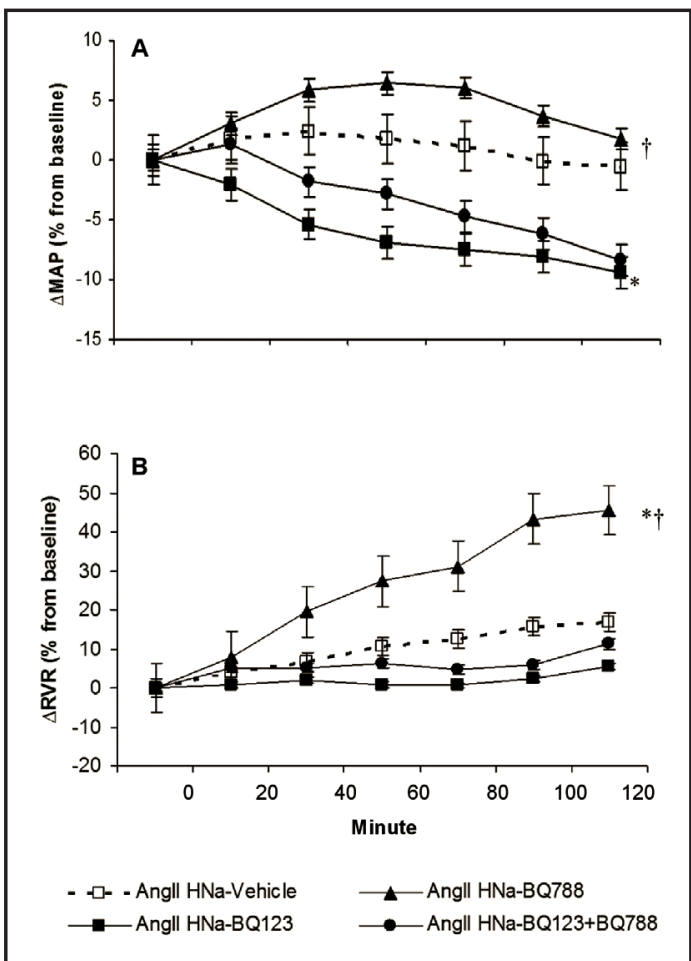

Fig. 1. Changes in (A) mean arterial pressure (MAP) and (B) renal vascular resistance (RVR) in response to intravenous BQ123, BQ788, BQ123 + BQ788 or vehicle isotonic saline in hypertensive Sprague-Dawley rats subjected to chronic Ang IIinfusion and high $\mathrm{NaCl}$ ( $\mathrm{HNa}$ ) diet (see Methods). Drug administration was started at time zero (see Methods). Values are means \pm SEM. The area under/ over the curve was used for comparisons between groups. A $P$ value $<0.05$ was considered statistically significant. ${ }^{*} P<0.05$ vs. AngII HNa-Vehicle, $\dagger P<0.05$ AngII HNa-BQ788 vs. AngII HNa-BQ123+BQ788.

remained largely positive in the frequency range of the TGF in groups AngII $\mathrm{HNa}-$ vehicle, AngII HNa-BQ123 and AngII HNaBQ788 (Table 2 and Figures S1-3). These results are in accord with our previously published data [21]. In general, group AngII HNa-BQ123+BQ788 showed less pronounced abnormalities compared to other groups at baseline (Table 2 and Figure S4). Endothelin receptor antagonists did not produce any statistically significant changes vs. vehicle in the investigated transfer function variables (Table 2 and Figures S1-4).

\section{Discussion}

In this model of hypertension caused by chronic Ang II-infusion and a high dietary $\mathrm{NaCl}$ intake, renal hemodynamics is characterized by a marked increase in RVR accompanied by reduced RBF and an impaired dynamic RBFA [21]. The main findings of the present

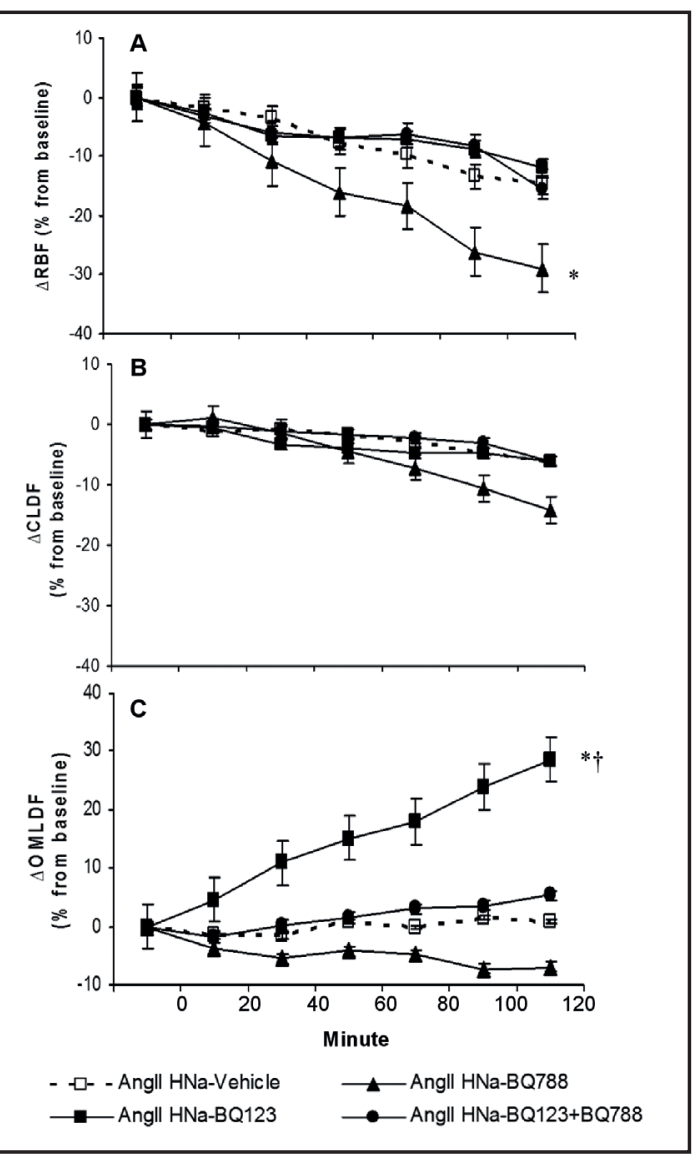

Fig. 2. Changes in (A) renal blood flow (RBF) and renal (B) cortical (CLDF) and (C) outer medullary (OMLDF) laser-Doppler fluxes in response to intravenous BQ123, BQ788, BQ123 + BQ788 or vehicle isotonic saline in hypertensive SpragueDawley rats subjected to chronic Ang II-infusion and high $\mathrm{NaCl}(\mathrm{HNa}$ ) diet (see Methods). Drug administration was started at time zero (see Methods). Values are means \pm SEM. The area under/ over the curve was used for comparisons between groups. A $P$ value $<0.05$ was considered statistically significant. ${ }^{*} P<0.05$ vs. AngII HNa-Vehicle, $† P<0.05$ AngII HNa-BQ123 vs. AngII HNa-BQ123+BQ788. 


\section{Kidney \\ Blood Pressure Research}

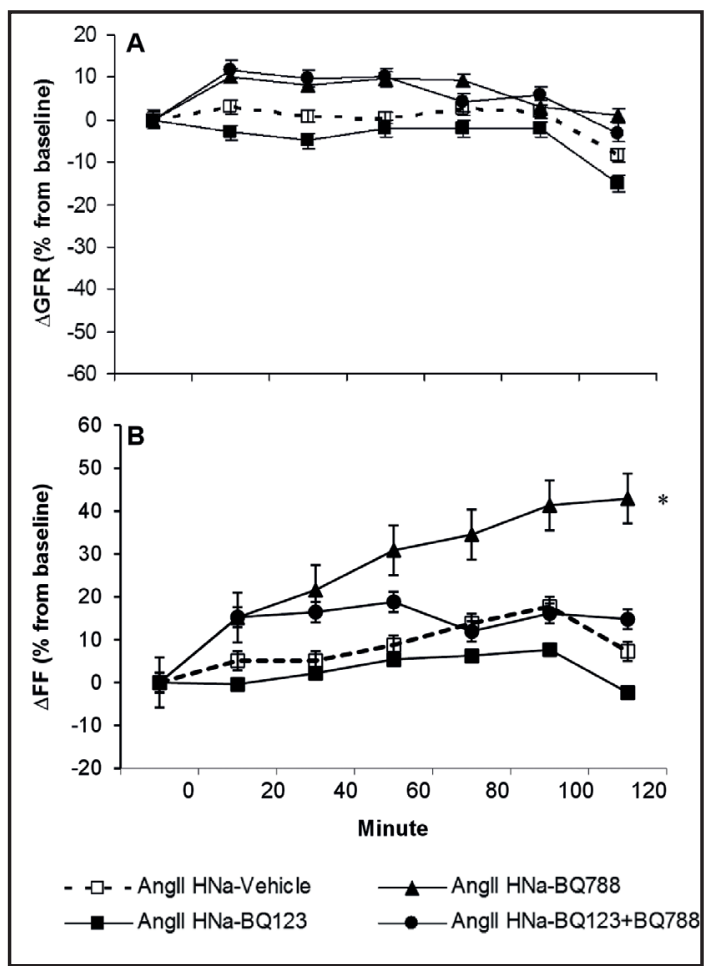

Fig. 3. Changes in (A) glomerular filtration rate (GFR) and (B) filtration fraction (FF) in response to intravenous BQ123, BQ788, BQ123 + BQ788 or vehicle isotonic saline in hypertensive SpragueDawley rats subjected to chronic Ang II-infusion and high $\mathrm{NaCl}(\mathrm{HNa})$ diet (see Methods). Drug administration was started at time zero (see Methods). Values are means \pm SEM. The area under/ over the curve was used for comparisons between groups. A $P$ value $<0.05$ was considered statistically significant. ${ }^{*} P<0.05$ vs. AngII HNa-Vehicle.

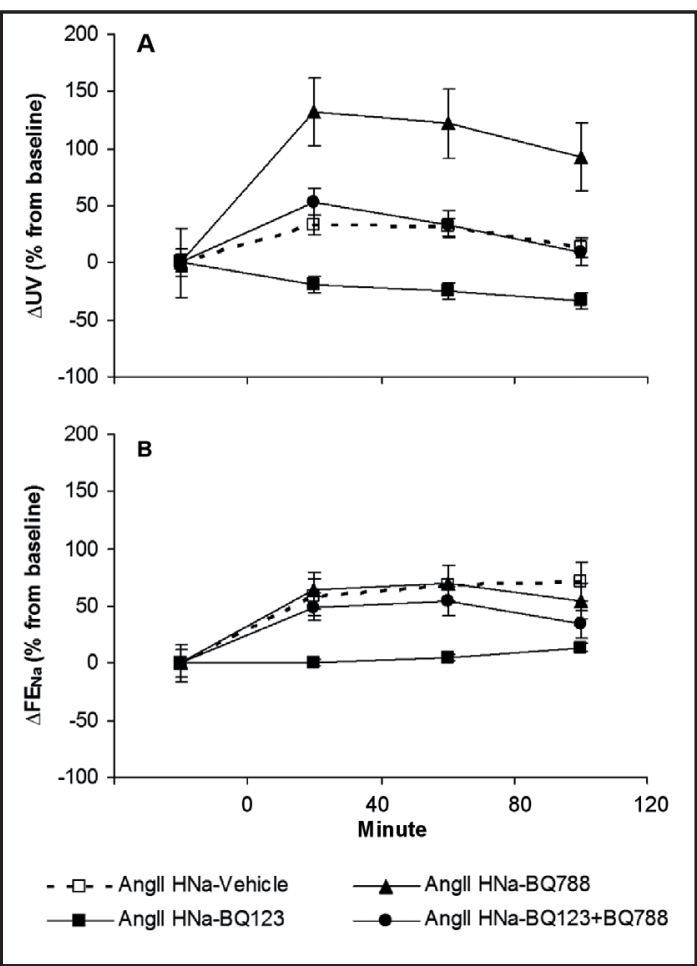

Fig. 4. Changes in (A) urine flow rate (UV) and (B) fractional urinary sodium excretion $\left(\mathrm{FE}_{\mathrm{Na}}\right)$ in response to intravenous BQ123, BQ788, BQ123 + BQ788 or vehicle isotonic saline in hypertensive Sprague-Dawley rats subjected to chronic Ang IIinfusion and high $\mathrm{NaCl}$ ( $\mathrm{HNa}$ ) diet (see Methods). Drug administration was started at time zero (see Methods). Values are means \pm SEM. The area under/ over the curve was used for comparisons between groups.

study were that the selective $\mathrm{ET}_{\mathrm{A}}$ receptor antagonist $\mathrm{BQ}-123$ reduced MAP and produced a selective increase in outer medullary $(\mathrm{OM})$ perfusion without affecting total or cortical RBF. On the contrary, the $\mathrm{ET}_{\mathrm{B}}$ receptor antagonist BQ-788 reduced RBF and increased RVR. Finally, neither $\mathrm{ET}_{\mathrm{A}}$ and/or $\mathrm{ET}_{\mathrm{B}}$ receptor antagonists attenuated abnormalities in dynamic RBFA that were characterized by an impaired myogenic response.

BQ-123 reduced MAP in Ang II-infused rats on high $\mathrm{NaCl}$ intake indicating a role for $\mathrm{ET}_{\mathrm{A}}$ receptors in this model of hypertension. This result supports previous findings with $\mathrm{ET}_{\mathrm{A}}$ receptor antagonists in similar models $[18,33]$. Interestingly, combined ETA and ETB receptor antagonism attenuated the reduction in MAP caused by ETA receptor antagonist alone. Furthermore, although the overall effect of BQ-788 on MAP did not reach statistical significance, we observed that BQ-788 induced a transient small increase in MAP. In accord with our finding, Boesen et al. [33] have demonstrated that $\mathrm{ET}_{\mathrm{B}}$ receptor blockade transiently enhanced the severity of hypertension in AngII-infused rats on a high $\mathrm{NaCl}$ intake. Taken together, these findings suggest an antihypertensive role for $\mathrm{ET}_{\mathrm{B}}$ receptors in AngII-infused animals on a high $\mathrm{NaCl}$ intake. Notably, selective $\mathrm{ET}_{\mathrm{A}}$ receptor antagonism with $\mathrm{BQ}-123$ specifically increased $\mathrm{OM}$ perfusion by approximately $30 \%$ despite reducing MAP. The vasodilation caused by BQ-123 in the renal medulla may have antihypertensive effects by increasing urinary sodium and water excretion and by facilitating pressure natriuresis [34]. 


\section{Kidney Blood Pressure Research}

Table 2. Characteristics of the transfer function between AP and RBF at baseline and during clearance periods 7-8 (C7-C8)

\begin{tabular}{lcccc}
\hline & Baseline & \multicolumn{2}{c}{ C7-C8 } & \multicolumn{2}{c}{ Baseline } & C7-C8 \\
\hline & \multicolumn{2}{c}{ AngII HNa-vehicle (n=8) } & \multicolumn{2}{c}{ AngII HNa-BQ788 (n=10) } \\
\hline Gain, 0.03-0.06 Hz, dB & $-0.02 \pm 0.50$ & $0.43 \pm 0.70$ & $-0.11 \pm 0.38$ & $1.27 \pm 1.20$ \\
Gain, 0.06-0.09 Hz, dB & $1.26 \pm 0.50$ & $0.83 \pm 0.73$ & $0.97 \pm 0.37$ & $2.49 \pm 0.98 \ddagger$ \\
Gain, slope 0.08-0.18 Hz, dB/decade & $2.33 \pm 1.11$ & $1.88 \pm 1.93$ & $3.98 \pm 1.37$ & $3.93 \pm 1.29$ \\
Phase, 0.08-0.18 Hz, rad & $0.18 \pm 0.03$ & $0.09 \pm 0.03$ & $0.16 \pm 0.04$ & $0.14 \pm 0.04$ \\
\hline & \multicolumn{2}{c}{ AngII HNa-BQ123 (n=9) } & AngII HNa-BQ123+BQ788 (n=9) \\
\hline Gain, 0.03-0.06 Hz, dB & $0.78 \pm 0.58$ & $0.14 \pm 1.02$ & $-3.40 \pm 0.77^{*} \dagger$ & $-1.12 \pm 0.69$ \\
Gain, 0.06-0.09 Hz, dB & $1.37 \pm 0.40$ & $1.09 \pm 0.79$ & $-1.72 \pm 0.53^{*} \dagger$ & $-0.47 \pm 0.34$ \\
Gain, slope 0.08-0.18 Hz, dB/decade & $2.52 \pm 1.83$ & $-2.94 \pm 4.13$ & $8.93 \pm 2.18^{*}$ & $7.30 \pm 1.50$ \\
Phase, 0.08-0.18 Hz, rad & $0.10 \pm 0.04$ & $0.10 \pm 0.05$ & $0.31 \pm 0.06 \dagger$ & $0.33 \pm 0.06$ \\
\hline
\end{tabular}

Data are means \pm SEM. Gain values in the frequency range $0.03-0.06 \mathrm{~Hz}$ correspond to the TGF mechanism and values in the range $0.06-0.09 \mathrm{~Hz}$ reflect the myogenic response (see Methods). Data are from baseline clearance periods prior to administration of drugs and from the last two periods (i.e. C7-C8) 80-120 minutes after start of drug administration. Endothelin antagonists did not produce any changes in transfer function variables that were significantly different from responses in group AngII HNa-vehicle. ${ }^{*} P<0.05$ vs. baseline AngII HNa-vehicle and $+P<0.05$ vs. baseline Ang II HNa-BQ123 and Ang II HNa-BQ788.

In addition, an increase in OM perfusion could be beneficial by improving medullary tissue oxygenation in a situation where pronounced renal vasoconstriction could promote hypoxic tissue injury. In line with the effect on MAP, combined $\mathrm{ET}_{\mathrm{A}}$ and $\mathrm{ET}_{\mathrm{B}}$ receptor antagonism abolished the increase in OM perfusion produced by BQ-123 alone, indicating that the effect of BQ-123 was dependent on intact $\mathrm{ET}_{\mathrm{B}}$ receptor signalling. Previous results demonstrate that there is a complex interaction between $\mathrm{ET}_{\mathrm{A}}$ and $\mathrm{ET}_{\mathrm{B}}$ receptors in the regulation of renal medullary blood flow. Systemic infusion of ET-1 has been shown to selectively increase medullary perfusion via $\mathrm{ET}_{\mathrm{B}}$ receptors [7, 8, 35]. In addition, Vassileva et al. [9] showed that medullary vasodilation produced by Big ET-1, through ET $_{B}$ receptors, was more prominent in rats on a high $\mathrm{NaCl}$ intake compared to animals on normal $\mathrm{NaCl}$ intake. However, ET-1 has also been shown to cause renal medullary vasoconstriction via $\mathrm{ET}_{\mathrm{A}}$ receptors when infused directly into the medulla [36]. In addition, Silldorff et al. [37] demonstrated that ET-1 constricted isolated descending vasa recta in vitro and that this effect could be blocked by $\mathrm{ET}_{\mathrm{A}}$ antagonists. Taken together, a number of studies have demonstrated that ET-1 can cause both vasoconstriction and vasodilatation in the renal medulla depending on the experimental condition and the prevailing balance between $\mathrm{ET}_{\mathrm{A}}$ and $\mathrm{ET}_{\mathrm{B}}$ receptor stimulation. Considering that $\mathrm{OM}$ vasodilation by $\mathrm{BQ}-123$ seemed to be dependent on intact $\mathrm{ET}_{\mathrm{B}}$ receptor signalling in the present study one might have anticipated that selective $\mathrm{ET}_{\mathrm{B}}$ antagonism with $\mathrm{BQ}$ 788 should have reduced OM perfusion. However, although BQ-788 tended to reduce OM perfusion this decrease did not reach statistical significance. These seemingly discrepant results are difficult to explain and need to be investigated further. Still, our results indicate that the increase in OM perfusion caused by BQ-123 was not just a consequence of removal of $\mathrm{ET}_{\mathrm{A}}$ mediated vasoconstriction but also involved vasodilation via $\mathrm{ET}_{\mathrm{B}}$ receptors.

It is feasible to hypothesize that the increase in OM perfusion caused by BQ-123, which was dependent on $\mathrm{ET}_{\mathrm{B}}$ receptor stimulation, could exert antihypertensive effects in this model by increasing urinary sodium and water excretion and facilitating pressure natriuresis [34]. In support of this antihypertensive role of $\mathrm{ET}_{\mathrm{B}}$ receptors, rats deficient in $\mathrm{ET}_{\mathrm{B}}$ receptors [10] and mice with collecting duct-specific deletion of ET-1 [11], $\mathrm{ET}_{\mathrm{B}}$ receptors [12], or $\mathrm{ET}_{\mathrm{A}}$ and $\mathrm{ET}_{\mathrm{B}}$ receptors [13], develop salt-sensitive hypertension. In addition, rats chronically treated with $\mathrm{ET}_{\mathrm{B}}$ receptor antagonist [9], and mice with collecting duct-specific deletion of ET-1 [38] show a blunted pressure natriuresis relationship. Nevertheless, the increase in OM perfusion caused by BQ-123 in the present study was not associated with increased urinary sodium and water excretion suggesting that the reduction in MAP caused by BQ-123 during the 120 minute intervention period was independent of excretory function. Hence, we speculate that BQ-123 reduced MAP in the present study mainly by causing arterial vasodilation and by 


\section{Kidney Blood Pressure Research}

reducing total peripheral resistance. The reason why increased outer medullary perfusion was not accompanied by increased urinary sodium excretion in response to BQ-123 remains elusive. Theoretically one could speculate that the increase in medullary perfusion might not have been transmitted into an increase in renal interstitial hydrostatic pressure which is an important mediator of decreased tubular sodium reabsorption during pressurenatriuresis. Alternatively, it is possible that the experimental condition with high circulating Ang II levels could cause an increase in sodium reabsorption in distal tubular segments that would compensate for decreased passive tubular sodium reabsorption in upstream tubular segments mediated by an increase in outer medullary perfusion.

In the present study selective $\mathrm{ET}_{\mathrm{B}}$ receptor antagonism with BQ-788 caused a significant increase in RVR and a marked decrease in RBF of approximately 30\%. In addition both CLDF and OMLDF clearly tended to decrease although not reaching statistical significance. Combined $\mathrm{ET}_{\mathrm{B}}$ and $\mathrm{ET}_{\mathrm{A}}$ receptor antagonism fully prevented the changes in RVR and RBF produced by BQ-788 indicating that the renal vasoconstriction was completely dependent on ETA receptor stimulation. These results are in agreement with those previously reported in normotensive animals [22, 35, 39]. Still, it may seem contradictory that selective $\mathrm{ET}_{\mathrm{A}}$ antagonism with $\mathrm{BQ}-123$ alone did not have significant effects on RBF or RVR in the present study. A possible explanation is that $\mathrm{ET}_{\mathrm{B}}$ antagonism increased plasma levels of ET-1 as $\mathrm{ET}_{\mathrm{B}}$ receptors play an important role in clearance of ET-1 from the circulation [40]. Thus, increased plasma levels of ET- 1 produced by $\mathrm{ET}_{\mathrm{B}}$ antagonism could have caused an exaggerated renal vasoconstrictor response through $\mathrm{ET}_{\mathrm{A}}$ receptors. However, the potential increase in plasma levels of ET-1 by $\mathrm{ET}_{\mathrm{B}}$ receptor antagonism in the present study remains hypothetical as measurements of plasma ET-1 were not performed. Interestingly, selective $\mathrm{ET}_{\mathrm{B}}$ receptor antagonism with $\mathrm{BQ}-788$ in the present study had no significant effect on GFR despite reducing RBF and hence $\mathrm{FF}$ increased. These results suggest that $\mathrm{ET}_{\mathrm{B}}$ receptor antagonism predominantly increased RVR by constriction of efferent arterioles. Also this effect was abolished by combined $\mathrm{ET}_{\mathrm{A}}$ and $\mathrm{ET}_{\mathrm{B}}$ receptor antagonism indicating that the increase in efferent arteriolar resistance was mainly caused by $\mathrm{ET}_{\mathrm{A}}$ receptor stimulation. In accord with our findings, Inscho et al. [41] have demonstrated that $\mathrm{ET}_{\mathrm{A}}$ receptor blockade prevents ET-1-mediated vasoconstriction of efferent arterioles.

We have previously demonstrated that dynamic RBFA is impaired in Ang II-infused rats, and exaggerated by a high $\mathrm{NaCl}$ intake, and that these abnormalities were attenuated by the superoxide dismutase mimetic tempol [21]. As ET-1 has been shown to stimulate NADPH oxidase activity and superoxide production $[42,43]$ we speculated that ET receptor antagonists might attenuate abnormalities in RBFA in this model. Confirming our previous results, Ang II-infused rats on a high $\mathrm{NaCl}$ diet displayed marked impairment in dynamic RBFA, mainly affecting the myogenic response. However, acute administration of ET receptor antagonists did not have any significant effects on dynamic RBFA, clearly suggesting that ET-1 is not involved in these defects in autoregulatory behaviour.

\section{Conclusion}

In Ang II-infused rats on a high $\mathrm{NaCl}$ diet $\mathrm{ET}_{\mathrm{A}}$ antagonism with $\mathrm{BQ}-123$ reduced $\mathrm{AP}$ and increased OM perfusion without affecting total or cortical RBF. These potentially beneficial effects were attenuated or abolished by combined $\mathrm{ET}_{\mathrm{A}}$ and $\mathrm{ET}_{\mathrm{B}}$ antagonism, clearly indicating an important role for $\mathrm{ET}_{\mathrm{B}}$ receptors in mediating the hemodynamic effects. In addition, ET receptor antagonists did not attenuate abnormalities in dynamic RBFA in this model.

\section{Conflict of Interests}

None 


\section{Kidney \\ Blood Pressure Research}

Kidney Blood Press Res 2012;36:258-267

\begin{tabular}{l|l}
\hline DOI: $10.1159 / 000343415$ & C 2012 S. Karger AG, Basel
\end{tabular}

Published online: November 26, 2012

www.karger.com/kbr

Saeed/DiBona/Guron: Endothelin and Renal Hemodynamics

\section{Acknowledgements}

The technical assistance of Elisabeth Grimberg is acknowledged. This study was supported by grants from the Swedish Heart-Lung Foundation, the Göteborg Medical Society, the Swedish Medical Society, the Swedish Association for Kidney Patients, Swedish Society of Nephrology, and Britt Wennerström's Research Foundation. G. F. DiBona was supported by research grants from the Adlerbertska Forskningsstiftelsen, The Royal Society of Arts and Sciences, Göteborg, Sweden, and Karolinska Institute, Stockholm, Sweden.

\section{References}

1 Kohan DE, Rossi NF, Inscho EW, Pollock DM: Regulation of blood pressure and salt homeostasis by endothelin. Physiol Rev 2011;91:1-77.

- Verhaar MC, Strachan FE, Newby DE, Cruden NL, Koomans HA, Rabelink TJ, Webb DJ: Endothelin-A receptor antagonist-mediated vasodilatation is attenuated by inhibition of nitric oxide synthesis and by endothelin-B receptor blockade. Circulation 1998;97:752-756.

$\$ 3$ Just A, Olson AJ, Arendshorst WJ: Dual constrictor and dilator actions of ET(B) receptors in the rat renal microcirculation: interactions with ET(A) receptors. Am J Physiol Renal Physiol 2004;286:F660-F668.

4 Kohan DE: Biology of endothelin receptors in the collecting duct. Kidney Int 2009;76:481-486.

5 Zhang Y, Jose PA, Zeng C: Regulation of sodium transport in the proximal tubule by endothelin. Contrib Nephrol 2011;172:63-75.

6 Kitamura K, Tanaka T, Kato J, Eto T, Tanaka K: Regional distribution of immunoreactive endothelin in porcine tissue: abundance in inner medulla of kidney. Biochem Biophys Res Commun 1989;161:348-352.

7 Gurbanov K, Rubinstein I, Hoffman A, Abassi Z, Better OS, Winaver J: Differential regulation of renal regional blood flow by endothelin-1. Am J Physiol 1996;271:F1166-F1172.

-8 Hercule HC, Oyekan AO: Role of NO and cytochrome P-450-derived eicosanoids in ET-1-induced changes in intrarenal hemodynamics in rats. Am J Physiol Regul Integr Comp Physiol 2000;279:R2132-R2141.

-9 Vassileva I, Mountain C, Pollock DM: Functional role of ETB receptors in the renal medulla. Hypertension 2003;41:1359-1363.

10 Gariepy CE, Ohuchi T, Williams SC, Richardson JA, Yanagisawa M: Salt-sensitive hypertension in endothelin-B receptor-deficient rats. J Clin Invest 2000;105:925-933.

11 Ahn D, Ge Y, Stricklett PK, Gill P, Taylor D, Hughes AK, Yanagisawa M, Miller L, Nelson RD, Kohan DE: Collecting duct-specific knockout of endothelin-1 causes hypertension and sodium retention. J Clin Invest 2004;114:504-511.

12 Ge Y, Bagnall A, Stricklett PK, Strait K, Webb DJ, Kotelevtsev Y, Kohan DE: Collecting duct-specific knockout of the endothelin B receptor causes hypertension and sodium retention. Am J Physiol Renal Physiol 2006;291:F1274-F1280.

13 Ge Y, Bagnall A, Stricklett PK, Webb D, Kotelevtsev Y, Kohan DE: Combined knockout of collecting duct endothelin A and B receptors causes hypertension and sodium retention. Am J Physiol Renal Physiol 2008;295:F1635-F1640.

14 Dohi Y, Hahn AW, Boulanger CM, Buhler FR, Luscher TF: Endothelin stimulated by angiotensin II augments contractility of spontaneously hypertensive rat resistance arteries. Hypertension 1992;19:131-137.

-15 Alexander BT, Cockrell KL, Rinewalt AN, Herrington JN, Granger JP: Enhanced renal expression of preproendothelin mRNA during chronic angiotensin II hypertension. Am J Physiol Regul Integr Comp Physiol 2001;280:R1388-R1392.

-16 Sasser JM, Pollock JS, Pollock DM: Renal endothelin in chronic angiotensin II hypertension. Am J Physiol Regul Integr Comp Physiol 2002;283:R243-R248.

-17 Bohm F, Pernow J, Lindstrom J, Ahlborg G: ETA receptors mediate vasoconstriction, whereas ETB receptors clear endothelin-1 in the splanchnic and renal circulation of healthy men. Clin Sci (Lond) 2003;104:143151.

18 Ballew JR, Fink GD: Role of ET(A) receptors in experimental ANG II-induced hypertension in rats. Am J Physiol Regul Integr Comp Physiol 2001;281:R150-R154.

19 Allcock GH, Venema RC, Pollock DM: ETA receptor blockade attenuates the hypertension but not renal dysfunction in DOCA-salt rats. Am J Physiol 1998;275:R245-R252. 


\section{Kidney \\ Blood Pressure Research}

Kidney Blood Press Res 2012;36:258-267

\begin{tabular}{l|l}
\hline DOI: $10.1159 / 000343415$ & C 2012 S. Karger AG, Basel
\end{tabular}

Published online: November 26, 2012

www.karger.com/kbr

Saeed/DiBona/Guron: Endothelin and Renal Hemodynamics

20 Ikeda T, Ohta H, Okada M, Kawai N, Nakao R, Siegl PK, Kobayashi T, Maeda S, Miyauchi T, Nishikibe M: Pathophysiological roles of endothelin-1 in Dahl salt-sensitive hypertension. Hypertension 1999;34:514519.

-21 Saeed A, DiBona GF, Marcussen N, Guron G: High-NaCl intake impairs dynamic autoregulation of renal blood flow in ANG II-infused rats. Am J Physiol Regul Integr Comp Physiol 2010;299:R1142-R1149.

22 Matsuura T, Miura K, Ebara T, Yukimura T, Yamanaka S, Kim S, Iwao H: Renal vascular effects of the selective endothelin receptor antagonists in anaesthetized rats. Br J Pharmacol 1997;122:81-86.

23 Ishikawa K, Ihara M, Noguchi K, Mase T, Mino N, Saeki T, Fukuroda T, Fukami T, Ozaki S, Nagase T, et al.: Biochemical and pharmacological profile of a potent and selective endothelin B-receptor antagonist, BQ788. Proc Natl Acad Sci U S A 1994;91:4892-4896.

24 Qiu C, Samsell L, Baylis C: Actions of endogenous endothelin on glomerular hemodynamics in the rat. Am J Physiol 1995;269:R469-R473.

25 Spratt JCS, Goddard J, Patel N, Strachan FE, Rankin AJ, Webb DJ: Systemic ETA receptor antagonism with BQ-123 blocks ET-1 induced forearm vasoconstriction and decreases peripheral vascular resistance in healthy men. British Journal of Pharmacology 2001;134:648-654.

26 Strachan FE, Spratt JC, Wilkinson IB, Johnston NR, Gray GA, Webb DJ: Systemic blockade of the endothelin-B receptor increases peripheral vascular resistance in healthy men. Hypertension 1999;33:581-585.

-27 Nitescu N, Grimberg E, Ricksten SE, Guron G: Effects of N-acetyl-L-cysteine on renal haemodynamics and function in early ischaemia-reperfusion injury in rats. Clin Exp Pharmacol Physiol 2006;33:53-57.

28 Smits GJ, Roman RJ, Lombard JH: Evaluation of laser-Doppler flowmetry as a measure of tissue blood flow. J Appl Physiol 1986;61:666-672.

29 Nitescu N, Grimberg E, Guron G: Low-dose candesartan improves renal blood flow and kidney oxygen tension in rats with endotoxin-induced acute kidney dysfunction. Shock 2008;30:166-172.

-30 Cupples WA, Braam B: Assessment of renal autoregulation. Am J Physiol Renal Physiol 2007;292:F1105-F1123.

-31 Just A: Mechanisms of renal blood flow autoregulation: dynamics and contributions. Am J Physiol Regul Integr Comp Physiol 2007;292:R1-R17.

-32 Wang X, Ajikobi DO, Salevsky FC, Cupples WA: Impaired myogenic autoregulation in kidneys of Brown Norway rats. Am J Physiol Renal Physiol 2000;278:F962-F969.

-33 Boesen EI, Pollock JS, Pollock DM: Contrasting effects of intervention with ETA and ETB receptor antagonists in hypertension induced by angiotensin II and high-salt diet. Can J Physiol Pharmacol 2010;88:802-807.

34 Cowley AW, Jr: Role of the renal medulla in volume and arterial pressure regulation. Am J Physiol 1997;273:R1-R15.

-35 Evans RG, Madden AC, Oliver JJ, Lewis TV: Effects of ET(A) - and ET(B)-receptor antagonists on regional kidney blood flow, and responses to intravenous endothelin-1, in anaesthetized rabbits. J Hypertens 2001;19:1789-1799.

-36 Nakano D, Pollock DM: Contribution of endothelin A receptors in endothelin 1-dependent natriuresis in female rats. Hypertension 2009;53:324-330.

37 Silldorff EP, Yang S, Pallone TL: Prostaglandin E2 abrogates endothelin-induced vasoconstriction in renal outer medullary descending vasa recta of the rat. J Clin Invest 1995;95:2734-2740.

-38 Schneider MP, Ge Y, Pollock DM, Pollock JS, Kohan DE: Collecting duct-derived endothelin regulates arterial pressure and Na excretion via nitric oxide. Hypertension 2008;51:1605-1610.

-39 Nitescu N, Grimberg E, Herlitz H, Guron G: Role of endothelin ET(A) and ET(B) receptor subtypes in the regulation of intrarenal blood flow and oxygen tension in rats. Clin Exp Pharmacol Physiol 2008;35:12271232.

40 Fukuroda T, Fujikawa T, Ozaki S, Ishikawa K, Yano M, Nishikibe M: Clearance of circulating endothelin-1 by ETB receptors in rats. Biochem Biophys Res Commun 1994;199:1461-1465.

41 Inscho EW, Imig JD, Cook AK, Pollock DM: ETA and ETB receptors differentially modulate afferent and efferent arteriolar responses to endothelin. Br J Pharmacol 2005;146:1019-1026.

$\checkmark 42$ Elmarakby AA, Loomis ED, Pollock JS, Pollock DM: NADPH oxidase inhibition attenuates oxidative stress but not hypertension produced by chronic ET-1. Hypertension 2005;45:283-287.

$\$ 43$ Li L, Fink GD, Watts SW, Northcott CA, Galligan JJ, Pagano PJ, Chen AF: Endothelin-1 increases vascular superoxide via endothelin(A)-NADPH oxidase pathway in low-renin hypertension. Circulation 2003;107:1053-1058. 